\title{
Policy Perspectives on Green School Guidelines: Connecting School Science with Gardens to Envision a Sustainable Future
}

\author{
Kamal Prasad Acharya ${ }^{1}$, Chitra Bahadur Budhathoki ${ }^{1}$, Birgitte Bjønness ${ }^{2} \&$ Linda Jolly ${ }^{2}$ \\ ${ }^{1}$ Central Department of Education, Tribhuvan University, Kirtipur, Kathmandu, Nepal \\ ${ }^{2}$ Department of Mathematical Sciences and Technology, Faculty of Environmental Sciences and Technology, \\ Norwegian University of Life Sciences, Norway \\ Correspondence: Kamal Prasad Acharya, Department of Science and Environment Education, Central \\ Department of Education, University Campus, Tribhuvan University, Kirtipur, Kathmandu, Nepal. Tel: \\ 984-1395-628. E-mail: kamalacharya@tucded.edu.np
}

Received: November 7, 2019

Accepted: May 6, $2020 \quad$ Online Published: May 28, 2020

doi:10.5539/jsd.v13n3p102

URL: https://doi.org/10.5539/jsd.v13n3p102

\begin{abstract}
The purpose of this paper is to explore the perspectives of teacher educators and policy experts on 'Green School Guidelines' and 'One Garden One School' educational policies in Nepal. This paper also examines how these educational policies help to attain sustainable development goals through education for sustainable development. It aims to explore ways for effective implementation of these policies for activity-based science learning in the school garden. The qualitative method was used to explore the perspectives of science and environment teacher educators and central level policy experts. The data were collected from semi-structured in-depth interviews and informal conversations. The data from both these sources were analyzed thematically around the concepts of education for sustainable development, its implementation strategies and challenges, and life skills development among students through school gardening activities. The study found that teacher educators and policy experts positively view the Green School Guidelines and One Garden One School implementation strategies. Nevertheless, to achieve policy aims, local organization needs to play a major role in the effective implementation of green school guidelines. The findings from this study are expected to encourage the Nepal government, local governments, and community schools to bring central level policies into local practices.
\end{abstract}

Keywords: education for sustainable development, school garden, science learning, sustainable future

\section{Introduction}

The Ministry of Education (MoE), and the Government of Nepal (GoN) launched the country's first Green School Guideline in 2017, which aims to promote environment conservation education in public schools. The purpose is to engage students in the school garden as a part of pedagogy aiming to meet the Sustainable Development Goals (SDGs). This guideline promotes the concept of One Garden, One School in the schools as a living laboratory. Garden-based pedagogy creates possibilities to support teaching and learning of science in schools. Education for Sustainable Development (ESD) triggered innovations in teaching and learning worldwide in the form of alternative methodologies (e.g. garden-based pedagogy, eco-pedagogy) that can strengthen people's sustainable development-related capacities (Aftandilian, \& Dart, 2013; Moffatt, 2015; Wals, \& Kieft, 2010). Wals and Kieft, (2010) argue that ESD in formal education is necessary for providing students opportunities to participate in addressing challenges in society.

Connecting pedagogy with sustainable issues, Dlouhá, \& Pospíšilová, (2018) argue that to achieve sustainable societies, students and communities should themselves, bear responsibility for their life and social environment. To this end, they need to learn relevant skills and decision-making through pedagogy for sustainable society. Green school guidelines assume that everyone can have an impact on policy; and students should thus be educated in a manner which uses the school garden for learning science In connection with this, research argues that together with formal schools, collaborative action among students, teachers, and parents plays a strong role in shaping the society. The public image of science education in Nepal may be one of simply learning facts by rote to achieve high scores (Acharya, 2016). Science education in recent history generally concentrates on the teaching of science concepts and lecturing on the fallacies of some concepts. Supporting the view of Duit (2016), school gardens are the natural places where students can acquire hands on learning experiences like working 
with seed germination in botanical science. There are opportunities to learn science that can be directly linked with the curriculum and science textbooks (Acharya, 2019).

Taking into consideration the main ideas of science for a sustainable future, the Nepal Government prepared the draft education policy One Garden One School. They did this by using the expertise of teacher educators and policy experts who had been teachers at the schools for a long time. These teachers were appointed as the teacher educators in the Curriculum Development Centre (CDC). The Nepal government is committed to focusing on how science education can contribute to sustainable development. It is believed, by the policy experts (Note 1) and teacher educators, that science education has a central role in education for sustainable development (ESD). To achieve the SDG's, the Nepal Government drafted the education policies of Green School Guideline and One Garden One School to be implemented in all the community schools in Nepal. This policy is based on the core roles that science education can play in the sustainable development of society if all the schools establish a garden and use it as an arena for learning science. It has been noted that science education should emphasize students' understanding of the role of science and also increase scientific literacy to contribute to sustainable communities (Burmeister \& Eilks, 2012; Wheeler, 2000).

In an overview of the role of school science in education for a sustainable future, Jegstad \& Sinnes (2015) concluded that "understanding the relations and interdependence of nature and society is considered crucial to achieving sustainability" (p. 7). Similarly, Eilks, (2015) argues that science and technology represent central aspects of any sustainable development, making science education especially responsible for integrating ESD into teaching and learning. Thus, the wanted changes put forward by the curricula reforms, based on One Garden One School policy, puts emphasis on garden-based science teaching and learning in the community schools. School science engages students the most when they consider it relevant to their lives and interests (Jegstad \& Sinnes, 2015). Connecting teaching science with gardening activities illustrates that there is an important opportunity for improvement when it comes to making science education context-oriented and relevant for students' personal and social lives.

Experiences in the natural world have an important influence on people's thinking in relation to the environment (Malone, 2008; Palmer, 1998), but the positive experiences need to occur over long periods of time (Hungerford $\&$ Volk, 1990). Consequently, including outdoor education in science may have the positive effect of engaging students in sustainability issues and caring for nature (Sandell \& Ohman, 2010).

This study was a part of a Participatory Action Research (PAR) project. Tribhuvan University (TU) from Nepal, in collaboration with the Norwegian University of Life Sciences (NMBU) has initiated the Rupantaran (Note 2) project, 2016-2021, entitled "Innovation in Teaching and Learning through Contextualized Approaches to increase the Quality, Relevance and Sustainability of Education in Nepal". The Norwegian Agency for Development Cooperation (NORAD) funded projects aimed at working with innovative, participatory, and rights-based approaches to improve teaching and learning outcomes of basic school students through community empowerment, gender equality, and sustainable improvements. The first and second authors talked with science and environment teacher educators and a policy expert from the Curriculum Development Centre (CDC) under the Ministry of Education (MoE), GoN. The first and second authors explored the perspectives of the policy expert and the teacher educators who drafted and prepared Green School guidelines and One Garden One School education policies and who also planned implementation strategies in the community schools throughout Nepal. Subject experts were high school science and environment teachers with more than ten years' experience. It is important to understand the perspectives of the policy experts and teacher educators in order to effectively implement the policy documents in the real field, and to be able to cope with the challenges and obstacles. The policy experts and teacher educators drafted and prepared the policy documents on the basis of their experiences as school teachers. We used in-depth semi-structured interviews and conversations with one central level policy expert and two subject experts to explore their perspectives on green school guideline education policy. The study is guided by the following research question:

What are the perspectives of the policy expert and the teacher educators on Green School Guidelines and One Garden One School to envision sustainable future?

\section{Methodology}

\subsection{Study Design}

A qualitative research design was used in this study by employing semi-structured in-depth interviews and conversations as the tools of data collection, to gain a more complete and in-depth understanding of the policy expert's and teacher educators' perspectives. Within a friendly and open atmosphere, the first and second authors explore how they made sense of Green School Guidelines and One Garden One School policy documents and 
how policy is shaped as a part of school science education.

\subsection{Ethics}

Consent was given to involve research participants for the study and it was expected that they would not be exposed to any significant risks. Furthermore, throughout the in-depth interviews and conversations, it was emphasized that 'research participation was voluntary' (Iphofen, \& Tolich, 2018) and that the participants were free to withdraw from the study at any moment without having to provide reasons or face any consequences.

\subsection{Research Participants}

The enrollment procedure started by inviting science and environment teacher educators with more than ten years' experience in community schools to participate. The central level policy expert has twenty years' experience in drafting and implementing educational policies in school-level education. Before recruiting respondents for the study, the first and second authors did a survey at the Curriculum Development Centre (CDC) with the teacher educators who were involved in the preparation of the education policy documents, asking about their academic and experiential backgrounds, and their working experiences. The first and second authors took a week to research the background and contributions of ten teacher educators and policy experts in the field of education. Two teacher educators (science and environment subjects) were chosen to participate in this study as they were involved in drafting and designing the policy documents. Another participant was the central level policy expert who is the director-general of the CDC with much experience in preparation of policy documents. Purposive-convenient sampling was used to identify and select teacher educators and the policy expert, as the intention of our study was to explore the perspectives of the policy documents throughout the study period.

\subsection{Data Collection Procedure}

The research on which this article is based is an exploratory and descriptive (Creswel, 2009) study that explores and describes the perceptions and perspectives of teacher educators and policy experts regarding Green School Guidelines and One Garden One School educational policies. These policy documents are ready to implement in the community schools by the Government of Nepal. To explore the policy perspective on school gardening for a sustainable future, it was necessary to have face-to-face communications with teacher educators and the policy expert to collect their opinions on policy documents and school gardening activities for learning science. During an in-depth interview, audio was collected was then transcribed based on our (first and second authors) judgments of relevance (Gee, 2004, Thomas, 2011). Each of the interviewees participated in an hour and a half in-depth interview (appendix A) plus an extra twenty minutes for conversations regarding their overall reflections on the policy documents. The total time used to collect data through in-depth interviews and conversations was about six hours. Interview questions were linked by the first and second authors on garden-based learning, sustainable development goals, science curricular activities, and most importantly, on the green school guidelines policy documents.

\subsection{Data Analysis}

Descriptive research (Creswell, 2009, Erickson, 2012) design was applied to analyze the perspectives of the teacher educators' and the policy expert. Data analysis was started from the initial meeting at the CDC office, i.e., when the first and second authors first began the conversations informally. All the interviews were transcribed and translated and then, together with the expanded conversation notes, were analyzed using thematic content analysis (Denzin \& Lincoln, 2008; 2011; Thomas, 2011). Themes emerged from the data through a process of open coding and theme refinement without restricting the analysis by predefined codes and themes (Denzin \& Lincoln, 2011). This process took place in three steps: open coding, categorization, and abstraction (Denzin \& Lincoln, 2011). Firstly, data were transcribed from all semi-structured interviews and the first author performed an open coding using the software ATLAS.ti for qualitative analysis, searching the data for significant features relevant to our interest. Secondly, the first author noted the themes of the study such as school garden and sustainable future, activity-based science learning, life skills development, and education for sustainable development. Thirdly, to refine the theme, the first author searched for relationships among the themes.

Since all data were collected in the Nepali language, the data analysis was performed in Nepali. During data analysis and write up of the manuscript, the original Nepali quotes were used as much as possible to prevent loss of meaning as a result of translation. The quotes in the final manuscript were translated by the first author and checked by the language expert.

The findings of the analysis are presented in the form of themes connected to each of the four dimensions to pinpoint the perspectives and challenges for effective implementation of Green School Guidelines through One Garden One School policy in schools in Nepal. 


\section{Findings}

The policy expert and teacher educators' perspectives on the policy documents Green School Guidelines and One Garden One School are presented around four main themes.

- Understanding how the Green School Guidelines and One Garden One School education policies aim to meet sustainable development goals through education for sustainable development;

- Implementation strategies of Green School Guidelines;

- Development of life skills through activity-based science learning in the school garden; and

- Challenges and obstacles for implementing Green School Guidelines and One Garden One School policy documents in the community schools throughout Nepal.

\section{Theme 1: Implementation of Green School guidelines may contribute towards meeting SDG through ESD}

The green school guidelines policy document focuses on the construction of a school garden in each school and the integration of teaching and learning science through gardening activities. This document also focuses on raising awareness among students for environmental conservation, as well as the transmission of knowledge to the community to meet the related environmental conservation aims of SDG. Under this theme, all interviewees perceived the possibility for effective implementation of the policy guidelines to meet SDG, but the interviewees were critical regarding the possibility of effectively implementing green school policy in all the community schools. One of the participants R2 who is a science teacher educator argued:

Students can learn a lot from the garden when they are meaningfully engaging in activities. Planting flowers, fruits, vegetables, and medicinal plants in the school garden helps to maintain greenery in the school. As school is a part of the wider community, knowledge related to maintaining the vegetation can be transferred to the surrounding community and that helps meet SDG to some extent.

Respondent R1 is a health and environment subject expert focused on engaging students in the garden for science learning activities and making them aware of how to conserve the environment. He worried about how to construct and maintain a school garden in all the schools due to a lack of resources. This could create difficulties in achieving the goal of a sustainable future

In the query of how teacher educators perceived school garden policy, respondent R1 shared her thoughts in her own words:

The purpose of making the school garden is for maintaining a learning center. The garden is the living laboratory where students and teachers can get direct experiences in nature. Almost all the subjects can be taught from the garden, but science is an important subject to teach in the garden. Segregation of wastes, solid waste management, preparation of compost, and rainwater harvesting are some of the topics that can be taught from the garden. These activities would help to maintain vegetation in the school and conserve the local environment, if we are able to link up gardening activities as a part of the science and environment subject. I hope this practice ultimately aims to meet SDG's through school education.

This is in line with respondent R1. Respondent R3 who is the central level policy expert stated:

Contribution to science learning for sustainable development is vital. Science education no longer needs to stop at the point where teaching is limited to describing the theories of science and knowledge behind sustainability issues and the potential avenues of action. Science lessons and school life morph into an action-based pattern of living and learning.

These responses of teacher educators and policy experts argue for the importance of green school guidelines for a healthy school environment. The concept of a sustainable future through garden-based pedagogy can be made. The opinions of the interviewees were in line with implementation of green school policy and may aid in meeting sustainable development goals in relation to environmental conservation. However, they were critical about linking all science content with the green school policy and school gardening activities throughout the community schools in Nepal.

Teacher educators were positive and optimistic towards linking teaching content with gardening activities and stated that effective implementation of the policy requires discussions among teachers about curriculum reform. We cannot enable a sustainable future simply by the incorporation of teaching contents without engaging students in the garden-based activities. It demands integration of the subject matter with gardening activities. 


\section{Theme two: Implementation Strategies of Green School}

In an opinion about One Garden One School and its implementation strategies for teaching and learning, respondent R1 elaborated her thoughts as follows:

The concept of 'earning and learning' is an important aspect of green school guidelines education policy. Students learn from the garden-based activities and at the same time they produce vegetables for the mid-day meal. This reduces the expense of mid-day meal cost. Also, students develop a healthy mind in a healthy body from the garden-based pedagogy. These are only a few aspects of the green school policy. For effective implementation of green school guidelines, local governments should manage minimum financial resources and monitoring actions. Municipalities and rural municipalities have to play a vital role to implement and control the quality of community schools.

Similarly, respondent R3 was in agreement with respondent R1 and argued:

......major role of the central government needs to be providing only the resources to the local bodies. I think the School Management Committee (SMC) has a major role for effective implementation of green school guidelines. To ensure the quality of education, parents and local bodies have significant roles. It will be more reliable if the district education coordination committee supervises the effective implementation of green school guideline policy to ensure the quality of education in each school.

Furthermore, respondent R2 stated, concerning the implementation strategies to ensure a sustainable future:

For the effective implementation of school garden policy in the community schools throughout Nepal, we need to integrate the garden with child-friendly and agro-based organizations such as Red Cross Society, eco-clubs, and child-clubs. We may coordinate the concept of green school guidelines with the World Health Organization for its effective implementation.

The above views of the respondents clearly show that the local government and community people have major roles and responsibilities to design, apply, and take care of the garden in the community schools. It can be more sustainable if the school has good collaboration with the local, national, and international organizations.

Under the theme of available resources for the school garden programme, policy expert R3 further stated:

.... green school guidelines policy demands land for each school but many schools in Nepal do not have their own land for garden construction. For example, many community schools in the Kathmandu valley do not have a small piece of landmass. It would be difficult for us to implement this policy very effectively. Accountability and responsibility of the stakeholders are also the major issues for the effective implementation of green school guidelines.

Both teacher educators, R1 and R2, agreed on a strategy to effectively implement the policies saying:

In our roles as teacher educators, we will share the importance of school gardening activities in training sessions with the school head teachers. We will plan and allocate time, with at least one session in the Teachers' Professional Development programmes, to convey this message to head teachers to implement this policy effectively. Teachers will learn the importance of the green school guideline and how it can be linked with the $S D G$ 's.

The above views of the respondents relative to the implementation strategies of green school clearly indicate that the difficulty of effective policy implementation is due to lack of adequate open land for the garden, and the responsibility of the SMC and PTA.

\section{Theme three: Life Skills Development through School Gardening Activities}

Regarding activity-based science learning at the school garden and life skills development among students, respondent R3 was focused on learning from the living laboratory and he stated the following:

...science is one of the major subjects that can be learned from gardening activities. Many aspects of biology and a few contents of physics and chemistry can also be taught through gardening activities. The principles of health and environment education such as natural resources, environmental balance, solid waste management, and environmental hazards are related to nature and these principles can be learned from the garden. Language subjects such as Nepali and English, as well as mathematics can also be learned through gardening activities. These areas certainly develop life skills related to environmental conservation among the students.

Similarly, respondent R2 supported the views of respondent R3 and she further elaborated this concept: 
Mathematical skills like counting, playing, and calculation; conversation, debating, and argumentation skills are related to language subjects; collaboration and social skills related to social study subjects can also be linked with the school gardening activities. The skills of science like motivation, curiosity, confidence, critical thinking, and analysis can also be developed through school gardening activities. The school garden provides the strategy to teach all the subjects so far, I think. All these skills prepare a mature and responsible person as he/she learns life skills from the school with an activity-based pedagogical approach.

All the respondents' perspectives clearly show that the garden is an important arena for learning to develop different life skills. So, we have to launch an integrated teaching and learning approach through school gardening activities for the overall development of the student. Developing life skills helps to ensure a sustainable future and it seems possible through ESD.

Along the same line, respondent R2 further stated:

Learning by doing and learning by living are the major parts of science education which relate to the garden. Science related contents such as water cycles, ecosystem, greenhouse effects, and environmental hazards are a few of the contents that can be taught through garden-based pedagogy.

The school garden helps to use the locally available resources and their application in teaching and learning. It hopes to promote the SDG's through school education. Almost all the components of an ecosystem are found in the garden and it is knowledge that will help students to understand the importance of a healthy environment. The transformation of this knowledge to the broader community helps to meet the targeted goals of a sustainable society through education for sustainable development (ESD).

Similarly, in the query of developing life skills through school gardening activities, respondent R1 argued in her own words:

... A strong bond exists between school gardening activities and basic skills for livelihood. Skills related to solid waste management, separation of bio-degradable and non-bio-degradable wastes, preparation of compost manure, care of the soil, irrigation, and handling apparatus are simple but important life skills that need to be developed among students. So, I think, gardening is an important aspect of life and livelihood.

Connecting the perspective of respondent $\mathrm{R} 1$, and respondent $\mathrm{R} 3$ further:

The use of alternative sources of energy minimizes pollution which is one of the aims of green school guideline policy. It helps to make our health better. ... The school garden is related to activities like caring and growing plants, irrigation, and preparation of compost manure, balancing the oxygen and carbon cycle, and the importance of photosynthesis to balance the ecosystem. These areas of learning help to minimize environmental pollution and also keep people healthy. Such garden-based activities support the ability to develop healthy habits. Developing healthy habits among students and transmitting this knowledge to the wider society will help to meet a sustainable future, I think it helps to meet the $S D G$ 's in the long run.

All the respondents had similar thoughts related to life skills development from school gardening activities. Engaging students in the school garden as a part of daily teaching and learning activities develops life skills. Participation and collaboration with teachers and friends develop a habit of working together and being responsible. Students can learn skills like organizing tasks, respecting others' opinions, and finally coming to decisions.

\section{Theme four: Challenges and Obstacle for Implementation of Green School Guidelines Policy}

All research participants worried about the effective implementation of green school guidelines policy due to poor physical infrastructures of development in the school sector in Nepal. Respondent R1 worried about it and said:

One of the major challenges for the effective implementation of green school guidelines in the community schools is a lack of adequate physical infrastructures like buildings and landmass. Many schools in Nepal do not have adequate land to make a garden. The green school guidelines demand land for the construction of a garden in each school. It makes me worry. However, we can use small areas to grow plants, flowers, and vegetables for its effective implementation.

Respondent R3 agreed with respondent R1 and stated:

Major challenges are the poor supply of technical and economic resources. Accountability and 
responsibility are also the major challenges for the effective implementation of the school garden. To solve this problem, the school management committee (SMC) members, parent-teacher association (PTA) members, and the local bodies need to be copiously responsible and accountable.

Similarly, respondent R2 in agreement with respondents R1 and R3 argued that the major obstacles and challenges were:

Teaching science and environment in the garden may be a major difficulty for many teachers. They would have to design activities which may be one of the major challenges. Students require supervision while working in the school garden. Playing with tools, water and electricity may increase the health risk for children. Continuous supplies of a large number of gloves, gum boots and masks may be another challenge for the school administration. Taking care of vegetables and flowers during long holidays (e.g., a month holiday) is another issue and a challenge to effective implementation of the school garden. Feasibility of a school garden in all topography and an effective implementation of the garden-based pedagogy may create another problem. Continuous arrangements for funding to maintain the school garden is another challenge. Lack of teachers' experience in gardening may be another issue and challenge to implementing green school guidelines and one garden one school policy in all the community schools in Nepal.

All the respondents' perspectives clearly show that the major obstacles are the inadequate physical infrastructures such as: buildings and landmass for school gardens, feasibility of school gardens in all topography, effective implementation, funding for daily care and maintenance, responsible teachers to take care of the garden, and the poor linkage of school curriculum with the gardening activities. Still, they are hopeful for the implementation of the policies in the schools in Nepal.

The overall findings show that the teacher educators and policy expert realized that they could not clearly articulate the best way of doing school gardening activities for the sustainable future. However, they became more comfortable with the implementation strategies of the green school guidelines policy. All the respondents argued that the importance of green school guidelines can and will help to envision a sustainable future if we are able to implement it effectively throughout Nepal. It is argued that the actual execution of the policy needs curriculum reform discussions to integrate content with gardening activities. School gardening is a hope for developing life skills among students and for supporting a sustainable future. The difficulty of policy implementation may be due to lack of enough land, money, trained teachers and responsible stakeholders.

\section{Discussion}

The present study's contribution is to show the perspectives of teacher educators and a central level policy expert on Green School Guidelines and One Garden One School policy documents and their roles in envisioning a sustainable future. The analysis details the perceptions of the interviewees on One Garden One School and its implementation based on green school policy to envision a sustainable society. However, they had doubts about connecting all the science curriculum with the green school policy and engaging students in school gardening activities throughout the community schools in Nepal. The teacher educators questioned the effective implementation of the policy documents without discussions among school science teachers at a national level, on curriculum reform. Interviewees agreed that it is difficult to envision a sustainable future simply by the incorporation of teaching contents without engaging students in the garden-based activities. School gardening activities need to be integrated with science and environment as subject matter with the gardening activities in the school science curriculum.

The finding of the present study is in line with Ratcliffe et al., (2011) arguing that the promotion of garden-based education in schools is necessary to envision a sustainable society. Similarly, Williams, \& Dixon, (2013) noted that the impact of garden-based learning on academic outcomes of subjects such as science and social studies is positive. A mega study done by Williams and Dixon, between 1990 to 2010, found challenges to the implementation of school gardening activities. Similarly, Ozer, (2007), claims from their research findings that empowering students to play, work and learn from the school garden enables them to develop competencies to build teams capable of applying skills necessary for sustainability.

Furthermore, it is found that science and environment teacher educators and the policy expert agreed that an effective implementation of green school policy and sustainability is dependent on the support of parents and the local community. This finding is in line with Adomssent and colleagues (2007), who put forward the importance of knowledge transfer on environmental conservation from the school to the community, and as well from the community to the school. Adomssent and his team further argue that gardening integrated with curriculum assures meeting SDG's. It is found from the study that the development of life skills plays an important role for 
sustainability by linking science curriculum with gardening. The finding of the present study supports Adomssent argument that developing life skills helps to ensure a sustainable future (2006). The views of the teacher educators clearly show that the local government and community people have major roles and responsibilities to design, apply, and take care of the garden. The research finding of Maclean, \& Ordonez, (2007) is similar to this line of collaboration between school and local and national organizations.

All the respondents came with similar thoughts related to the development of life skills from engaging in daily school gardening activities. Participation and collaboration with the teachers and friends develop habits of working together and taking responsibility. Students can learn the skills like organizing the task, respecting others' opinions, and finally agreeing on a decision. This is in line with Cincera, Boeve-de Pauw, Goldman, \& Simonova, (2019) arguing that students' and teachers' feeling of ownership through school gardening is necessary to envision a successful sustainable community. However, learning from the home and the community outside of the classroom has an important role in obtaining a sustainable future and meeting the SDG's (Huang, Loo, Zhao, \& Chow, 2019). All the respondents argued that school gardening activities contribute to connecting school and society to help to meet SDG's. Connecting this perspective, Haydock, \& Srivastava, (2019) said: "environmental philosophies need to linkup teaching and learning that help to connect school and the community for SDGs" (p. 2). Similarly, Benavides (2017) suggests incorporating environmental education in the school curriculum in an integrated way to ensure a sustainable future. We still need to find out how the school science teachers meaningfully engaged in the garden in a collaborative way for a sustainable society; it may be a topic for further research. Last, but not least, it is anticipated that gardening activities may help to transform science teaching and learning through reflection and understanding of the nature of science.

\section{Limitations and Recommendations}

There are limitations to this study. First, because of time limits, only three in-depth interviews were done with the teacher educators of science, health and environment subjects as well as from the policy expert who is the director-general of the curriculum development center. This research article relates a small part of the entire three years of participatory action research (PAR) journey of the first author's Ph.D. study. We hope that this study can act as an invitation to other Nepalese community schools' science teachers, the Ministry of Education, researchers in relevant fields, relevant organizations, and policy-makers to engage in public discussion about the current practices and reforms in schools in Nepal that aim to shift classroom pedagogy towards meaningful engagement of students in school gardening activities. We also hope that such open discussions can lead to a new paradigm on garden-based science learning to transform the entire science pedagogical orientation in the community schools in Nepal. Recommendations include further research involving garden-based action research pedagogy; addressing all research participants' voices, experiences, insights, and reflections about teaching and learning science in community schools throughout Nepal; and targeting to fulfill the aim of sustainable development goals (SDG) through education for sustainable development (ESD).

\section{Acknowledgments}

We would like to thank the respondents (teachers and policy expert) who have provided time and valuable insights to us by participating in the study. This paper has been prepared with the support from NORHED/Rupantaran project entitled 'Innovations in Teaching and Learning through Contextualized Approaches to Increase the Quality, Relevance and Sustainability of Education in Nepal' which has been jointly implemented in Nepal by Tribhuvan University (TU), Kathmandu University (KU) and Norwegian University of Life Sciences (NMBU). Authors are grateful to the project coordinators for their valuable support. We would like to thank to the University Grants Commission for the support to publish this paper.

\section{Authors' Contributions}

KPA and CBB collected data. KPA transcribed, translated, interpreted the data, and drafted the manuscript. CBB, $\mathrm{BB}$, and LJ provided scholarly guidance and corrected the manuscript. All the authors read and approved the final version of the manuscript.

\section{Ethical Statement}

This research was conducted according to the guidelines laid down in the Declaration of Nepal Health Research Council (NHRC) and by the Nepal Government and all procedures involving human subjects were approved by the Ethics Committee of the NHRC. Consents were obtained from all the research participants.

\section{Authors' note}

This study is a part of the first author's doctoral dissertation. 


\section{References}

Acharya, K. P. (2016). Fostering critical thinking practices at primary science classrooms in Nepal. Research in Pedagogy, 6(2), 1-7. https://doi.org/10.17810/2015.30

Acharya, K. P. (2019). New perspectives on activity-based chemistry learning through meaningful engagement: Mystical improvement in students' achievement. American Journal of Creative Education, 2(3), 128-137. https://doi.org/10.20448/815.23.128.137

Adomssent, M., Godemann, J., Michelsen, G., Barth, M., Rieckmann, M., \& Stoltenberg, U. (2007). Developing key competencies for sustainable development in higher education. International Journal of sustainability in higher education.

Aftandilian, D., \& Dart, L. (2013). Using garden-based service-learning to work toward food justice, better educate students, and strengthen campus-community ties. Journal of Community Engagement and Scholarship, 6(1), 9.

Benavides L. A. I. (2017). Conceptions of environmental education in Mexican primary education: teachers' views and curriculum aims (Doctoral dissertation, University of Leeds). https://doi.org/10.1080/13504622.2018.1553235

Bucher, K. (2017). Opening garden gates: Teachers making meaning of school gardens in Havana and Philadelphia. Teaching and Teacher Education, 63, 12-21.

Burmeister, M., \& Eilks, I. (2012). An example of learning about plastics and their evaluation as a contribution to education for sustainable development in secondary school chemistry teaching. Chemistry Education Research and Practice, 13, 93-102. https://doi.org/10.1039/C1RP90067F

Cincera et al. (2019). Emancipatory or instrumental? Students' and teachers' perceptions of the implementation of the EcoSchool program. Environmental Education Research, 25(7), 1083-1104. https://doi.org/10.1080/13504622.2018.1506911

Creswel, J. W. (2009). Research design: Qualitative, quantitative, and mixed methods approaches. Los Angeles: University of Nebraska-Lincoln.

Denzin, N. K., \& Lincoln, Y. S. (2008). Collecting and interpreting qualitative materials (Vol. 3). Sage.

Denzin, N. K., \& Lincoln, Y. S. (Eds.). (2011). The Sage handbook of qualitative research. Sage.

Dlouhá, J., \& Pospíśilová, M. (2018). Education for Sustainable Development Goals in public debate: The importance of participatory research in reflecting and supporting the consultation process in developing a vision for Czech education. Journal of Cleaner Production, 172, 4314-4327. https://doi.org/10.1016/j.jclepro.2017.06.145

Duit, R. (2016). The constructivist view in science education-what it has to offer and what should not be expected from it. Investigaçôes em ensino de ciências, 1(1), 40-75.

Eilks, I. (2015). Science Education and Education for Sustainable Development-Justifications, Models, Practices and Perspectives. Eurasia Journal of Mathematics, Science \& Technology Education, 11(1).

Erickson, F. (2012). Qualitative research methods for science education. In B. J. Fraser, K. Tobin, \& C. J. McRobbie (Eds.), Second International Handbook of Science Education (pp. 1451-1469). Netherlands: Springer. https://doi.org/10.1007/978-1-4020-9041-7_93

Gee, J. P. (2004). An introduction to discourse analysis: Theory and method. Routledge.

Haydock, K., \& Srivastava, H. (2019). Environmental philosophies underlying the teaching of environmental education: a case study in India. Environmental Education Research, 25(7), 1038-1065. https://doi.org/10.1080/13504622.2017.1402170

Hoffman, A. M. (2006). The Capability Approach and educational policies and strategies: Effective life skills education for sustainable development. AFD, Paris.

Huang, et al. (2019). Incorporating personal experience in free-choice environmental learning: lessons from a zoological theme park. Environmental Education Research, 1-17. https://doi.org/10.1080/13504622.2019.1569203

Huckle, J., \& Wals, A. E. (2015). The UN Decade of Education for Sustainable Development: business as usual in the end. Environmental Education Research, 21(3), 491-505. https://doi.org/10.1080/13504622.2015.1011084 
Hungerford, H. R., \& Volk, T. L. (1990). Changing learner behavior through environmental education. The Journal of Environmental Education, 21(3), 8-21. https://doi.org/10.1080/00958964.1990.10753743

Iphofen, R., \& Tolich, M. (Eds.). (2018). The SAGE handbook of qualitative research ethics. Sage. https://doi.org/10.4135/9781526435446

Jegstad, K. M., \& Sinnes, A. T. (2015). Chemistry Teaching for the Future: A model for secondary chemistry education for sustainable development. International Journal of Science Education, 37(4), 655-683. https://doi.org/10.1080/09650792.2014.960531

Leal Filho, W., Manolas, E., \& Pace, P. (2015). The future we want: Key issues on sustainable development in higher education after Rio and the UN decade of education for sustainable development. International Journal of Sustainability in Higher Education, 16(1), 112-129. https://doi.org/10.1108/IJSHE-03-2014-0036

Maclean, R., \& Ordonez, V. (2007). Work, skills development for employability and education for sustainable development. Educational Research for Policy and Practice, 6(2), 123-140. https://doi.org/10.1007/s10671-007-9017-y

Malone, K. (2008). Every experience matters: An evidence based research report on the role of learning outside the classroom for children's whole development from birth to eighteen years. Report commissioned by Farming and Countryside Education for UK Department Children, School and Families, Wollongong, Australia.

McNiff, J. (2014). Writing and Doing Action Research. London: SAGE Publications. https://doi.org/10.4324/9781315738499

Moffatt, L. (2015). Surveying the field: Literacy education research for environmental sustainability. Literacy and Social Responsibility, 8(1), 3-14.

Ozer, E. J. (2007). The effects of school gardens on students and schools: Conceptualization and considerations for maximizing healthy development. Health Education \& Behavior, 34(6), 846-863.

Palmer, J. A. (1998). Environmental education in the 21st century-theory, practice, progress and promise. London: Routledge.

Plaka, V., \& Skanavis, C. (2016). The feasibility of school gardens as an educational approach in Greece: a survey of Greek schools. International Journal of Innovation and Sustainable Development, 10(2), 141-159. https://doi.org/10.1504/IJISD.2016.075546

Ramos, T. B., Caeiro, S., Van Hoof, B., Lozano, R., Huisingh, D., \& Ceulemans, K. (2015). Experiences from the implementation of sustainable development in higher education institutions: Environmental Management for Sustainable Universities. Journal of Cleaner Production, 106, 3-10. https://doi.org/10.1016/j.jclepro.2015.05.110

Ratcliffe, M. M., Merrigan, K. A., Rogers, B. L., \& Goldberg, J. P. (2011). The effects of school garden experiences on middle school-aged students' knowledge, attitudes, and behaviors associated with vegetable consumption. Health promotion practice, 12(1), 36-43.

Sandell, K., \& hman, J. (2010). Educational potentials of encounters with nature: Reflections from a Swedish outdoor perspective. Environmental Education Research, 16(1), 113-132. https://doi.org/10.1080/13504620903504065

Sauvé, L. (1996). Environmental education and sustainable development: A further appraisal. Canadian Journal of Environmental Education, 1, 7-34.

Shirazi, S. (2017). Student experience of school science. International Journal of Science Education, 39(14), 1891-1912. https://doi.org/10.1080/09500693.2017.1356943

Thomas, G. (2011). How to do your Case Study: A guide for students and researchers. Sage.

Wals, A. E., \& Kieft, G. (2010). Education for sustainable development: Research overview (No. 2010: 13). Sida. https://doi.org/10.1177/097340820900400106

Ware, S. A. (2001). Teaching chemistry from a societal perspective. Pure and Applied Chemistry, 73(7), 12091214. https://doi.org/10.1351/pac200173071209

Wheeler, K. A. (2000). Introduction. In K. A. Wheeler, \& A. P. Bijur (Eds.), Education for a sustainable future (pp. 1-5). New York, NY: Kluwer Academic/Plenum. https://doi.org/10.1007/978-1-4615-4277-3_1

Wiek et al. (2015). Operationalising competencies in higher education for sustainable development. In M. Barth, 
G. Michelsen, M. Rieckmann, \& I. Thomas (Eds.), Handbook of Higher Education for Sustainable Development (pp. 241-260).

Williams, D. R., \& Dixon, P. S. (2013). Impact of garden-based learning on academic outcomes in schools: Synthesis of research between 1990 and 2010. Review of Educational Research, 83(2), 211-235.

\section{Notes}

Note 1. Policy expert is the person who drafted and prepared green school guideline and one garden one school education policies.

Note 2. Rupantaran meaning transformation in Nepali language.

\section{Copyrights}

Copyright for this article is retained by the author(s), with first publication rights granted to the journal.

This is an open-access article distributed under the terms and conditions of the Creative Commons Attribution license (http://creativecommons.org/licenses/by/4.0/). 